\title{
accination des animaux sauvages contre la rage
}

Comme Anne Flamand l'a récemment rappelé dans ces colonnes, le renard roux est, en Europe, le principal réservoir du virus rabique, responsable de la progression de l'épizootie actuelle [I]. La solution adoptée jusqu'à ce jour pour lutter contre l'extension de la maladie est l'abattage massif des renards, mesure juste capable de ralentir la progression de l'épizootie et non de la stopper. La vaccination des animaux sauvages se heurte à d'évidentes difficultés de réalisation et exige en pratique l'administration par voie orale de vaccins vivants, virus atténués ou vecteurs recombinés. Le danger théorique des vaccins atténués est celui d'une réversion vers la virulence; un tel risque n'existe évidemment pas lorsque le gène codant pour une protéine vaccinante est transféré dans un vec- teur viral vivant peu dangereux, tel le virus de la vaccine [2].

La société Transgène de Strasbourg a réussi à produire un tel virus vaccinal recombiné par l'intégration du gène codant pour la glycoprotéine de surface du virus rabique [3]. Lorsqu'il est administré à des renards par l'intermédiaire de morceaux de viandes contaminés par le virus vaccinal recombiné, le vaccin permet le développement d'anticorps spécifiques et protège les animaux contre une infection ultérieure par le virus rabique virulent [4]. Malheureusement la protection vaccinale ne semble pas être "contagieuse " et pouvoir se propager d'un animal vacciné à un animal sensible. Associée à la poursuite de l'abattage des renards (pour maintenir des populations à faible densité), la vaccination antirabique des popu- lations sylvestres sensibles permet cependant d'entrevoir des moyens efficaces d'endiguer l'extension de cette terrible maladie [5].

Dans les pays du tiers-monde où la rage continue d'être une cause très importante de mortalité humaine [I], la vaccination des chiens et des chats errants devrait également permettre de diminuer la fréquence de l'affection.

A.K.

I. Flamand A. Actualité de la rage. médecine/sciences 1986; 2: 312-21.

2. Beaud $\mathrm{G}$. Vers un renouveau du virus de la raccine. médecine/sciences 1986; 2: 94-8. 3. Kieny MP, Lathe R, Drillien R, et al. Expression of rabies virus glycoprotein from a recombinant vaccinia virus. Nature $1984 ; 312$ : $163-6$.

4. Blancou J, Kieny MP, I.athe R, et al. Oral vaccination of the fox against rabies using a live recombinant vaccinia virus. Nature $1986 ; 322$ : 373-5.

5. Anderson RM. Vaccination of wildlife reservoirs Nature 1986; 322: 304-5.

\section{Un essai thérapeutique chez des jumeaux identiques atteints de myopathie de Duchenne}

En I98I, Mayana Zatz et coll. (Sao Paulo, Brésil) avaient observé un malade, alors âgé de I 3 ans, atteint simultanément de maladie de Duchenne et de déficit en hormone de croissance, chez lequel l'évolution de la myopathie se montrait particulièrement lente $[\mathrm{I}]$. L'hypothèse qu'ils ont émise d'un effet retardateur des inhibiteurs de la croissance sur la myopathie n'a pu être vérifiée correctement du fait des difficultés extrêmes des essais médicamenteux dans cette affection.
Zatz et Betti [2] ont tiré parti de l'étude de deux jumeaux identiques âgés de 7 ans, atteints de maladie de Duchenne, dont l'un a reçu, avec l'accord des parents, un traitement par un inhibiteur de la croissance, le mazindol, en double insu. Au bout d'un an l'état de santé du jumeau non traité s'est notablement détérioré, alors que celui du jumeau traité est resté stable et il est désormais capable de performances très supérieures à celles de son frère.

Sans vouloir tirer d'une telle obser- vation des conclusions abusives, on peut penser que cette expérience unique autorise quelques espoirs et pourrait justifier des essais systématiques dans cette maladie oú aucun médicament ne s'est encore montré efficace.

J.-C. D.

1. Zatz M, Betti RTB, Levy A. Benign Duchenne muscular dystrophy in a patient with growth hormone deficiency. Am 7 Med Genet I98I; I0: $301-4$.

2. Zatz M, Betti R. Assessment in double blind test of a drug therapy in monozygote twins affected with Duchenne Muscular Dystrophy. Muscle and Nerze 1986; 9: $5 \mathrm{~S}$ (suppl 273).

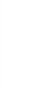

